\title{
On the role of communication and management engagement for acquisition success: A study of Israeli startups
}

\author{
Jan Polowczyk, Ofer Zaks, Piotr Trąpczyński
}

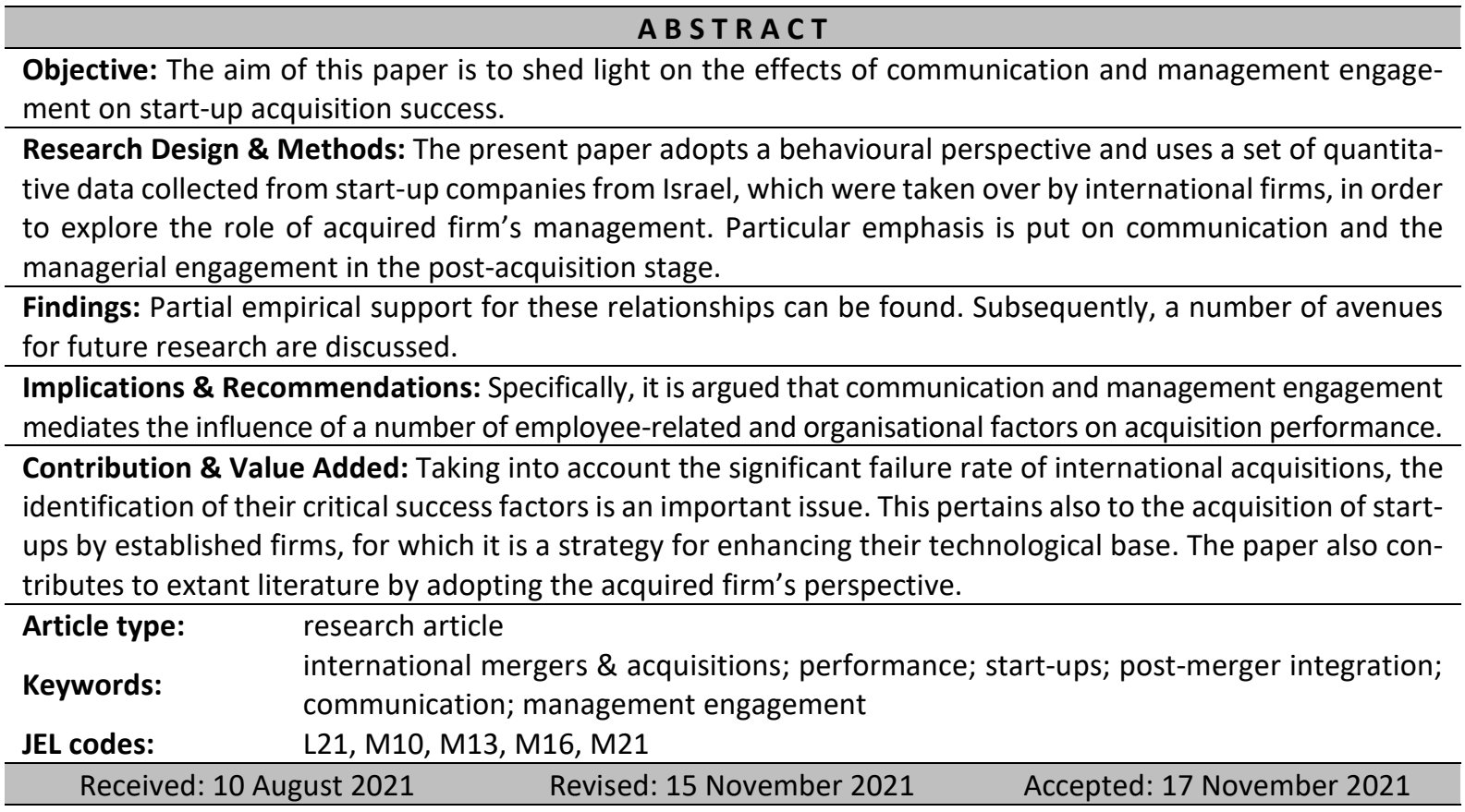

\section{Suggested citation:}

Polowczyk, J., Zaks, O. \& Trąpczyński, P. (2021). On the role of communication and management engagement for acquisition success: A study of Israeli startups. International Entrepreneurship Review, 7(4), 7-22. https://doi.org/10.15678/IER.2021.0704.01

\section{INTRODUCTION}

Due to significant competitive pressures in the global environment, firms need to be able to introduce new products and services rapidly (Cefis \& Marsili, 2006). Therefore, constant innovation plays a vital role for firm performance in the long run (Cai et al., 2017; Cheng \& Yang, 2017). Hence, established companies often recur to mergers and acquisitions (M\&A) in order to benefit from the technological assets of smaller companies which pose a source of innovation (Zaks et al., 2018).

Indeed, start-up acquisition can be regarded as a crucial way of enhancing the technological knowhow by mature organisations (Agarwal \& Helfat, 2009; Santos \& Eisenhardt, 2009). However, in spite of their vital role for firm competitiveness, a significant number of technological M\&A do not meet their objectives (King et al., 2008). This may be related to the fact that the know-how which is accessed by the acquiring firms is mostly complex, contextual and rooted in a interpersonal networks (Ranft \&Lord, 2002). Furthermore, M\&A targets are often small and medium-sized enterprises (SMEs), as well as start-up companies. Hence, the risk that the business cultures and processes of the acquiring and acquired firms will not be aligned, is even higher (Popli et al., 2017). And yet, in extant literature many 
M\&A-related studies concentrate on the success factors on the side of the acquiring firm (Becker et al., 2016; Cheng \& Yang, 2017; Rahman et al., 2016).

In fact, the behavioural side of M\&A has long been analysed from the viewpoint of various approaches, such as the individual psychological view (Amiot et al., 2006; Angwin et al., 2015), the social view (Terry et al., 1996), or the cultural perspective (Jordão et al., 2014). To a large extent, though, this research has been inconsistent in its approaches and findings (Seo \& Hill, 2005). Extant research has indicated that the performance of M\&A is indeed dependent on the behaviour of the target firm's employees, including particularly trust (Inkpen \& Currall, 2004; Stahl et al., 2012) and commitment to change (Van Dam, 2005; Wanberg \& Banas, 2000).

On the other hand, organisational variables affected by the acquirer, such as the extent of knowhow transfer towards the target firm (Junni et al, 2015; Zollo \& Meier, 2008), or the extent to which the target firm may remain autonomous (Whitaker, 2012), were also examined. At the same time, in light of extant knowledge it seems that those variables in themselves do not guarantee success, since appropriate communications (Galpin \& Herndon, 2007; Schweiger \& DeNisi, 1991), or a significant involvement of the acquired firm's employees in the entire takeover (e.g. Graebner, 2004) can turn out to be indispensable for the success of acquisitions.

Therefore, the aim of this article is to shed some additional light on variables which mediate the influence of employee-related and organisational variables on start-up acquisition success. Specifically, departing from expectancy theory (Vroom, 1964), we concentrate on the role of communication and management engagement as mediators.

These research objectives are addressed empirically within the context of start-ups from Israel, which are taken over by foreign firms. For several decades now, Israel has witnessed a massive increase in the number of takeovers in the technological area (Avnimelech \& Schwartz, 2009; Dashti et al., 2008). Moreover, Israel has developed a strong reputation for a pronounced entrepreneurial culture, top-notch technological know-how and an environment which is conducive to start-up growth (De Fontenay \& Carmel, 2004). The relevance of using this research context also resides in the fact that models addressing M\&A practices have mostly been proposed based on the experience of bigger transactions. In the present study it is argued that acquired firm-level factors leading to the success of acquisitions may be more accentuated for small and medium sized enterprises (Weitzel \& McCarthy, 2011).

\section{LITERATURE REVIEW AND HYPOTHESES DEVELOPMENT}

\section{Success determinants of acquisitions}

\section{Employee-related determinants}

Extant research stresses the relevance of trust in the mutual contacts of managers with their employees as a foundation of organisational change (Gomez \& Rosen, 2001; Trąpczyński et al., 2018). With regard to acquisitions, the concept of trust is often used in the context of the relationship between the acquirer and the acquired firm. Particularly during the period after the announcement of an acquisition, which is characterised by intensive risk evaluation, trust is easy to erode, yet harder to repair (Krug \& Nigh, 2001). A novel team of managers is usually mistrusted, since target firm employees may expect organisational changes which can affect their presence in the company (Hurley, 2006). Trust can pose an alleviating factor in relation to these employee fears (Van Dam, 2005). On the other hand, the readiness for change may be significantly afflicted if leaders behave in a different manner than what had been communicated to their subordinates (Simons, 2002). Therefore, on the whole, it can be expected that the employees' trust in management will positively affect the outcome of M\&A.

Further, the readiness and openness to change is crucial from the point of view the results of the change process, since employees may display ambiguous feelings with regard to the change process (Piderit, 2000). The degree to which the members of an organisation can contribute to the change process is significantly dependent on the information sharing across a number of different channels, as well as on the involvement of employees both in the preparation and execution stages of the entire process (Armenakis \& Harris, 2002). 
The results of extant research indicate that participants of the change processes displaying higher commitment, also demonstrate superior readiness to change, as well as the acceptance of change (Madsen et al., 2005). Studies exploring employee commitment have inter alia looked into its effects on turnover, job satisfaction and performance, or overall firm performance (Cooper-Hakim \& Viswesvaran, 2005).Existing results point to the fact that negative attitudes of target firm's employees towards the acquisition may be among important factors explaining the failure of acquisitions. And yet, this relationship has rarely been verified empirically (Datta, 1991; Larsson \&Finkelstein, 1999).

\section{Organisational determinants}

Extant studies have particularly focused on the relevance of knowledge flows from the headquarters to its affiliates as an important factor explaining organisational outcomes (Minbaeva et al., 2003; Zollo \& Meier; 2008). Such knowledge flows from the acquirer towards the acquired firm are related to the level of resources which employees dedicate to learning from the parent company and implementing the obtained know-how (Minbaeva, 2007).

Conversely, transfers to the acquirer are usually related to the know-how possessed by employees, such as their competences and skills (Junni \& Sarala, 2013). While knowledge transfers towards the parent firm have usually been connected to start-up takeovers, the flows towards the acquired firm can be conducive to post-merger performance (Junni et al., 2015; Oberg \& Tarba, 2013). There is a number of variables influencing the effectiveness of the knowledge transfer, such as the social ties between the members of both organisations (Vaara et al., 2012). On the whole, it can be expected that the knowledge transfer from the acquiring organisation will positively affect acquisition success.

Further, we posit that the strategy of the acquirer with regard to the autonomy granted to the target firm is another factor contributing to acquisition success. Although it may be necessary re-configure resources and integrate the two organisations so as to reap the benefits of the acquisition (Capron, 1999), the reduction of autonomy which is often triggered at the same time can actually contribute negatively to the entire transaction (Very et al., 1997). Also, it should be noted that for an integration process to be successful, it requires significant involvement by the management, diverting the acquiring firm's attention from its own focus (Schoar, 2002).

Indeed, the integration-autonomy dichotomy may be particularly important in acquisitions of technology companies. This type of transactions is often driven by the willingness to gain access to compound know-how(Puranam et al., 2002). However, the consolidation of both organisations can ultimately compromise the target firm's know-how if its employees leave the organisation (Ranft \&Lord, 2002). And yet, previous studies have often regarded the consolidation of the acquirer and the acquiring firm as a phenomenon to which the targetfirm is subjected, instead of acknowledging it as a process in which the management team of the target firm ought to take part to a significant extent.

\section{Managerial involvement by the acquired firm}

It is crucial to note that the success of an acquisition is contingent upon the responses of the management team of the target firm to any modifications of their mandate and scope of autonomy (Bezrukova, et al., 2012). Thus, in the ensuing subsections, attention is devoted to the significance of communication and managerial engagement on the part of the acquired firm.

\section{Acquired firm's communication in the integration period}

Effective communication during the process of consolidation of the acquiring and acquired firms entails a significant volume of information to be provided in a transparent, understandable and fair manner (Gomes et al., 2011). Within the integration stage of $M \& A$, the role of communication is to enable employees to gain insights into the ongoing processes and therefore to adjust their own knowledge of what will be expected from them in the new reality of their organisation (Birkinshaw et al., 2000).

Further, among the key factors contributing to an effective management of the acquisition process are the intensity and quality of related communications. The ambivalent responses of an organisation's members in the wake of an acquisition can be managed more effectively by recurring to well prepared 
and executed communications (Marks \& Mirvis, 2001). Providing realistic information to staff and management reduces undesirable uncertainty regarding jobs security, career advancement and the ongoing benefits associated with the acquisition(Galpin \& Herndon, 2007).

\section{Acquired firm's management engagement the post-acquisition integration}

From a theoretical perspective, expectancy theory emphasises the perceived odds that an outcome would indeed ensue as a consequence of a certain behaviour (Vroom, 1964). In the context of entrepreneurship, the subjective odds that a given new venture would lead to certain results is affected by personal opinions regarding the know-how required to leverage this business chance or the availability of resources which may be necessary for that goal(Feather, 1992). An important dimensions of the acquired firm's involvement pertains to the presence of the founder of the start-up firm who plays a key role in such organisation and its culture. After the accomplishment of the acquisition, higher commitment of the target firm's employees can help the acquirer to reduce employee turnover in the acquired firm, especially if the founder is also actively involved in the integration process (Rhoads et al., 2012). Accordingly, the acquisition of start-ups poses specific issues with regard to the decision as to whether to keep or replace the original top management team (TMT). Given that the founder is often inherently related to the technology which defines the start-up, as well as to the culture of the organisation, the engagement of him and his management team is a crucial prerequisite to ensure that employee-related factors can translate into success (Baum \& Locke, 2004; Rhoads et al., 2012).

\section{Analytical framework and research hypotheses}

To summarise the literature review presented above, we argue that from a behavioural perspective, while a number of employee-related factors, as well as organisational variables pertaining to the approach of the acquirer towards the target firm, are essential for the success of the acquisition, they alone are not able to explain acquisition performance. Indeed, it is the role of the acquired start-up's management to design and implement an appropriate programme of communication about the deal, as well as demonstrate its active participation in the consolidation of both organisations, in order to address anxiety, doubts and open issues on the part of the members of the organisation. Only then can both the employee attitudes, and objective support from acquiring firm, translate into performance outcomes.

Accordingly, in line with our research goals, we propose several hypotheses on the mediating effect of managerial communication and management engagement.

H1: The relationship between employee-related variables and acquisition performance is mediated by communication delivered to employees by the TMTs of the acquired firm.

H2: The relationship between organisational variables and merger success is mediated by communication delivered by the TMT of the acquired firm.

H3: The relationship between employee-related variables and acquisition performance is mediated by the engagement of acquired management during the post-acquisition integration.

H4: The relationship between acquired company's variables and merger success is mediated by the engagement of acquired management during the post-acquisition integration.

Figure 1 summarises the hypothesised relationships in a conceptual framework based on extant research.

\section{RESEARCH METHODOLOGY}

\section{Data collection and sample}

Our empirical study embraced high-tech start-ups from Israel which were taken over by foreign firms in the period 2009-2014 (Trąpczyński et al., 2018). Respondents were identified based on data from a number of sources. The majority of firms were extracted from lists including start-ups acquired during 2009-2014. 125 invitations were sent via e-mail through Qualtrics ${ }^{\mathrm{TM}}$ to leaders and top managers during the first quarter of 2015. While 105 surveys were opened, 53 respondents completed the survey, which corresponds to a $58 \%$ response rate. 


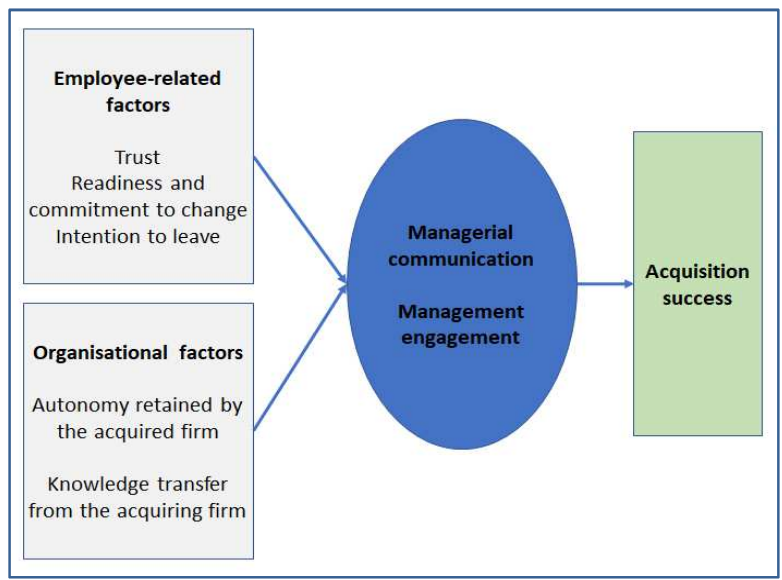

Figure 1. Conceptual framework

Source: own elaboration.

The size of the target firms varied from 5 to more than 200 employees, whereby $48 \%$ had $5-50$ employees (see Table 1).

Table 1. Sample characteristics

\begin{tabular}{|c|c|c|c|}
\hline Characteristics & Thresholds & $\#(N=53)$ & $\%$ \\
\hline \multirow{3}{*}{$\begin{array}{c}\text { Number of employees } \\
\text { (in the acquired company)/size }\end{array}$} & $5-50$ & 24 & 45.3 \\
\hline & $51-200$ & 13 & 24.5 \\
\hline & $201+$ & 16 & 30.2 \\
\hline \multirow[t]{3}{*}{ Previous experience in $M \& A$} & 0 & 25 & 47.2 \\
\hline & 1 & 14 & 26.4 \\
\hline & $2+$ & 14 & 26.4 \\
\hline \multirow[t]{3}{*}{ Age (group) } & $20-39$ & 6 & 11.3 \\
\hline & $40-59$ & 42 & 79.2 \\
\hline & $60+$ & 5 & 9.4 \\
\hline \multirow[t]{3}{*}{ Education } & Bachelor degree & 19 & 35.8 \\
\hline & Master degree + & 34 & 64.2 \\
\hline & $1-4$ & 16 & 30.2 \\
\hline \multirow[t]{2}{*}{ Tenure (years) } & $5-9$ & 19 & 35.8 \\
\hline & $10-$ & 18 & 34.0 \\
\hline \multirow{3}{*}{$\begin{array}{l}\text { Time since the merger } \\
\text { announcements ( years) }\end{array}$} & -2 & 16 & 30.2 \\
\hline & less & 22 & 41.5 \\
\hline & $4+$ more & 15 & 28.3 \\
\hline
\end{tabular}

Source: own study.

\section{Variables operationalisation}

\section{Dependent variable}

Firstly, perceived performance was adopted as a measure of acquisition performance. Numerous studies pointed to the fact that the evaluations delivered by executives are correlated with performance items based on objective data (e.g. Homburg \& Bucerius, 2006). While M\&A outcomes are to a certain degree inherently unpredictable, there is certainly a link between the TMTs' genuine motivations and post-M\&A performance (Coff, 1999). In the current study, out of nine potential questions regarding 'perceived performance', five were eventually chosen (Cronbach alpha= 0.87 ). Two examples of items for 'perceived performance' are: "To which extent your merger expectations before the acquisition were fulfilled?" and "Based on your perception, how many targets were accomplished?" The scale ranged from, 1(low) to 5(high). 
Further, acquisition satisfaction was conceptualised as the degree to which an employee anticipates feeling satisfied in the aftermath of the transaction. Participants were asked to indicate their satisfaction with the acquisition process, their satisfaction with their involvement in the implementation of the acquisition and their satisfaction with management performance $(1=$ very dissatisfied to 5 $=$ very satisfied). Out of seven potential questions five were eventually chosen to measure satisfaction (Cronbach alpha $=0.89$ ).

\section{Mediating variables}

The first mediator pertains to communication within the stage of integration of both companies, which can be described as the provision of information to employees with regard to various issues related to the integration process (see e.g. Jimmieson et al., 2004). The overall reliability alpha for integration characteristics amounted to0.79. Further, the quality of information pertaining to the change process was also captured with a four-item measurement scale adapted from Wanberg and Banas (2000). Questions were asked on a 5-point Likert-type scale, whereby $1=$ strongly disagree and $5=$ strongly agree. Six questions representing the quality of communication variable were chosen for this present study (out of fourteen potential questions). The alpha obtained was 0.75 .

Secondly, with regard to management engagement, in line with Graebner (2004) it was operationalised as a binary variable, set up as a dummy variable depending on whether the target firm retained its management team or whether they were substituted for by professional managers hired by the acquirer. Another item was added in order to measure the time period of the TMT presence following the acquisition public announcement.

\section{Independent variables}

As far as employee-related variables go, questions on trust were related to employees' beliefs with regard to the management's trustworthiness and fairness. Out of eleven potential questions based on extant literature (Oreg, 2006), the survey ultimately included six questions regarding trust. Items were operationalised on a five-point scale (with Cronbach's alpha amounting to 0.63 ).

Readiness for change was operationalised by the use of two types of scales: the first one by Holt et al. (2007) to evaluate the readiness at an individual level and the second by Meyer and Allen (1997) to assess affective organizational commitment. Seven questions represent this variable in our study (out of twelve that were judged and evaluated).

As far as organisational variables are concerned, autonomy removal was operationalised with three items regarding asymmetric shift in control from one firm to the other: (a) financial control, (b) administrative control and (c) operational control. After adding three further questions adopted from earlier studies (Ranft, 2006; Very et al., 1997), we finally constructed a scale with altogether six items and the alpha of 0.88 .

Moreover, in line with Schoenberg's (2006) study, we measured knowledge transfers between both organisations with regard to 11 areas. Ten items were chosen with Cronbach's alpha 0.88 . The scale consistently ranged from 1 to 5 .

\section{Control variables}

Acquired company's size was evaluated by asking respondents to provide the employment size before the acquisition. Prior experience with M\&A was operationalised as a binary variable(presence or lack of experience). Managers were also requested to provide the information how many M\&A they had experienced. Finally, respondents were requested to provide the sector in which their company is active.

\section{Analytical procedures}

This section presents the statistical procedures that were used in order to obtain a first understanding and then to analyse the data obtained through the Qualtrics survey system. It is important to present the basic descriptive statistics, presented in Table 2. The table includes the basic data (min, max, mean \& standard deviation- S.D.) of the quantitative research variables: dependent, independent and mediators. 
Subsequently, several Pearson correlation tests were carried out to provide an initial understanding of the relationships between the research variables. As indicated in Table 3, Pearson correlations are in general in line with the expectations formulated in the research hypotheses, hence providing some initial support for the studied relationships.

Table 2. Descriptive statistics

\begin{tabular}{|l|c|c|c|c|}
\hline \multicolumn{1}{|c|}{ Variable } & Min & Max & M & S.D \\
\hline Retained autonomy & 1.00 & 5.00 & 2.61 & 0.88 \\
\hline Knowledge transfer & 1.00 & 5.00 & 3.15 & 1.03 \\
\hline Trust & 1.33 & 5.00 & 3.27 & 0.88 \\
\hline Readiness and commitment to change & 1.80 & 4.80 & 3.75 & 0.68 \\
\hline Intention to leave & 1.00 & 5.00 & 3.08 & 1.17 \\
\hline Communication & 1.00 & 5.00 & 3.31 & 0.86 \\
\hline Perceived performance & 1.00 & 5.00 & 3.00 & 0.95 \\
\hline Satisfaction with acquisition & 1.00 & 5.00 & 2.99 & 1.12 \\
\hline Management engagement after acquisition & 0.00 & 1.00 & 0.89 & 0.32 \\
\hline
\end{tabular}

Source: own study.

Table 3. Pearson correlations

\begin{tabular}{|l|c|c|c|c|c|c|c|}
\hline \multicolumn{1}{|c|}{ Variables } & 1 & 2 & 3 & 4 & 6 & 7 & 8 \\
\hline Retained autonomy (1) & & & & & & & \\
\hline Knowledge transfer (2) & 0.038 & & & & & & \\
\hline Trust (3) & $0.267^{*}$ & 0.184 & & & & & \\
\hline Readiness \& commitment (4) & 0.188 & 0.144 & $0.516^{* *}$ & & & & \\
\hline Intention to leave (5) & $-0.364^{* *}$ & -0.176 & $-0.359^{* *}$ & $-0.253^{*}$ & & & \\
\hline Communication (6) & 0.221 & -0.003 & $0.709^{* *}$ & $0.586^{* *}$ & $-0.337^{* *}$ & & \\
\hline Performance (7) & 0.058 & $0.362^{* *}$ & $0.524^{* *}$ & $0.245^{*}$ & $-0.516^{* *}$ & $0.398^{* *}$ & \\
\hline Satisfaction with acquisition (8) & 0.150 & $0.382^{* *}$ & $0.704^{* *}$ & $0.327^{* *}$ & $-0.508^{* *}$ & $0.519^{* *}$ & $0.834^{* *}$ \\
\hline
\end{tabular}

Levels of significance: ${ }^{*} p<0.05 .^{* *} p<0.01 .^{* * *} p<0.001$

Source: own study.

Before focusing on the main results, it is crucial to note that most control variables had no significant influence over the study variables. However, some significant relationships were detected between the employment size of the acquired company and the other variables. More specifically, it was found that in large companies (more than 200 employees), there was a significant lower engagement of management participation in the integration process. Similar results emerged in relation to the variables of 'trust', 'readiness and commitment', 'communication' and 'satisfaction', where significant differences between small and large size organisations were detected. No significant effects were identified in relation to 'previous experience with acquisitions'.

After conducting descriptive statistical tests, we recurred to a series of path analyses which offers the advantage of directly testing the specified mediation model (Edwards \& Lambert, 2007). While path analysis can be regarded as a particular form of structural equation modelling (SEM), it has become widespread in research in which small sample size limits the application of a complete structural equation (Chaudhuri \& Holbrook, 2001). Path analysis is a form of multiple regressions focusing on causality. Overall, this method entails verifications of direct, indirect, and total effects of various values of the mediating variables. In order to address our hypotheses regarding the mediation effect of management's communication, as well as management engagement, separate path analyses were conducted. The models presented in the ensuing section consist of diagrams that specify the independent, mediating, and dependent variables, whereby regression weights are predicated by each computed model. Single-headed arrows show the causality between all variables. 


\section{RESULTS}

In the first path analysis, shown in Figure 2, the mediating effects of management's communication on the linkages between independent variables and acquisition performance, was examined. The findings indicate that management's communication is a significant mediator, although it has a relatively weak effect. Among the independent variables out of the five studied ones, only 'trust', 'intention to leave' (among employee-related variables) and 'knowledge transfer 1' (among organisational variables) turn out to be statistically significant.

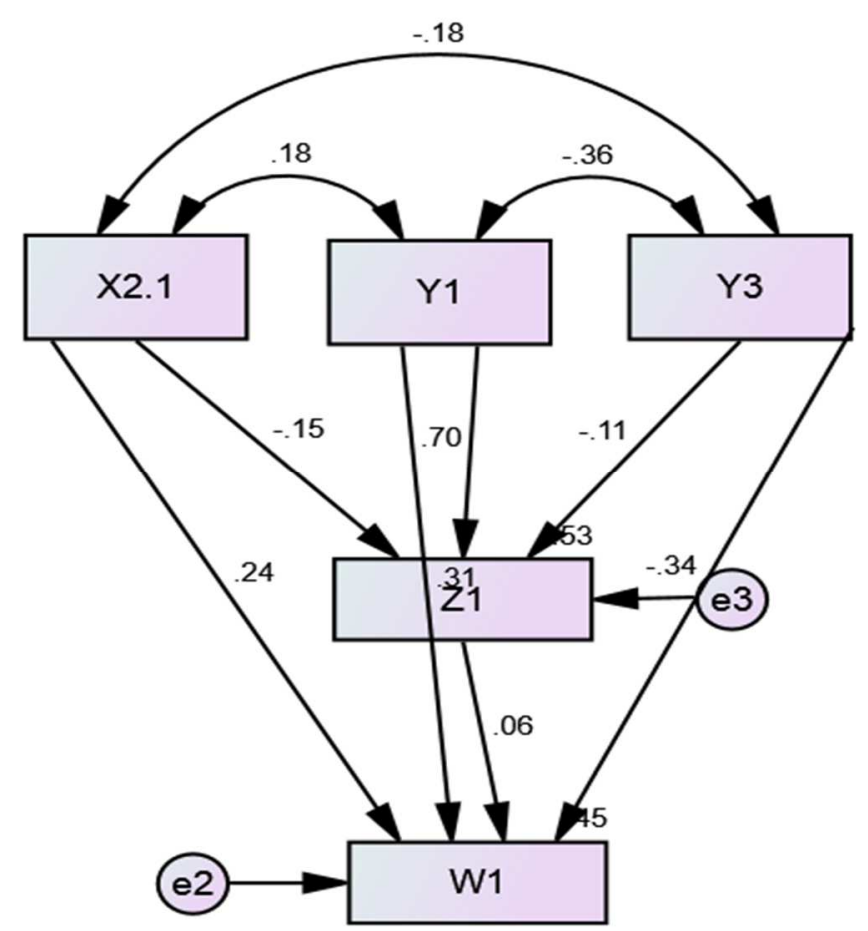

Figure 2. Path analysis model for 'perceived performance'

Annotation: dependent: W1 - perceived performance; mediator:Z1 - management's communication), inde-pendent variables: (X2.1 - retained autonomy, Y1 - trust, Y3 - intention to leave).

Source: own elaboration.

In the second analysis, depicted in Figure 3, the mediation of management's communication on the relationships between independent variables and satisfaction with acquisition was examined. The model illustrates management's communication to be a significant mediator, albeit with a limited influence. Similar to the first analysis, mediation for only three independent variables turns out to be significant: 'trust', 'intention to leave' and 'knowledge transfer 1 '.

Based on the two path analyses, it can be concluded that Hypotheses 1 and 2 were only partially supported by the results. The empirical evidence points to partial mediation, whereby the mediating variable accounts for a part of the relationship between the main research variables. In fact, there is not only a statistically significant linkage between managerial communication and both performance and on the other hand its antecedents, but also some direct relationships between our dependent and explanatory variables.

So as to examine Hypotheses 3 and 4, we first examined the direct influence of the mediating variable on the research variables. Because 'managements' engagement' is a dichotomous (categorical) variable, a series of t-tests were conducted. As demonstrated in Table 4, 'trust' was the only significant difference between the groups, indicating that in companies where management was present during the acquisition process, the level of trust was higher than in companies where management was not present. No other significant differences were found between companies with or without management engagement during the acquisition process. 


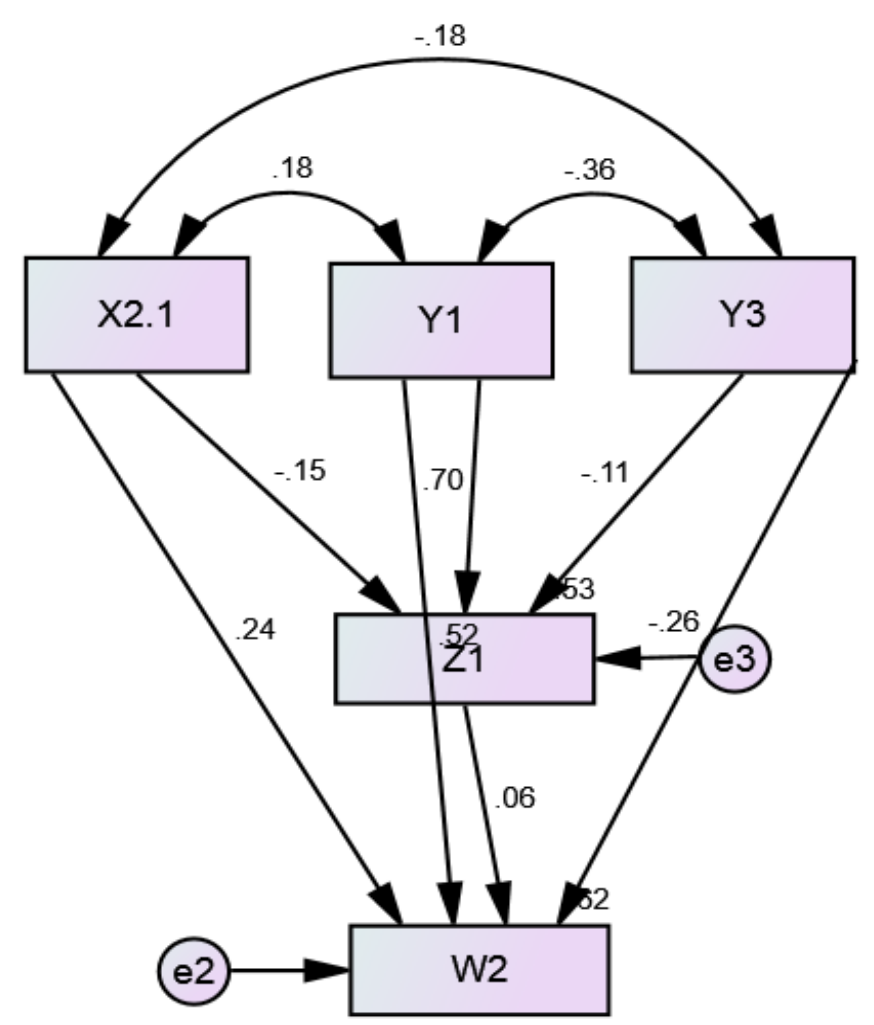

Figure 3. Path analysis model for 'satisfaction with acquisition'

Annotation: dependent: W2 - satisfaction with acquisition; mediator:Z1 - management's communication), independent variables: (X2.1 - retained autonomy, Y1 - trust, Y3 - intention to leave).

Source: own elaboration.

Table 4. T-test for independent groups to analysis between 'managements' engagement' and the other research variables

\begin{tabular}{|l|c|c|c|c|c|}
\hline \multirow{2}{*}{ Variables } & \multicolumn{2}{|c|}{ No } & \multicolumn{2}{c|}{ Yes } & \multirow{2}{*}{ t } \\
\cline { 2 - 6 } & \multicolumn{2}{|c|}{ (n=5) } & \multicolumn{2}{c|}{ (n=48) } \\
\cline { 2 - 6 } & $\mathbf{M}$ & S.D & M & S.D & \\
\hline Retained autonomy & 2.26 & 0.53 & 2.65 & 0.90 & -0.95 \\
\hline Knowledge transfer & 3.00 & 0.85 & 3.16 & 1.05 & -0.33 \\
\hline Trust & 2.30 & 0.41 & 3.37 & 0.86 & $-2.73 * *$ \\
\hline Readiness \& commitment & 3.36 & 0.89 & 3.79 & 0.66 & -1.34 \\
\hline Intention to leave & 3.72 & 1.22 & 3.01 & 1.16 & 1.29 \\
\hline Communication & 3.03 & 0.86 & 3.34 & 0.86 & -0.76 \\
\hline Performance & 2.56 & 1.13 & 3.05 & 0.93 & -1.09 \\
\hline Satisfaction with acquisition & 2.32 & 1.02 & 3.06 & 1.11 & -1.43 \\
\hline
\end{tabular}

$* p<0.05 . * * p<0.01 . * * * p<0.001$

Source: own study.

Next, two path analyses were conducted. In the first analysis, shown it Figure 4, the mediating effects of managements' engagement on the relations between independent variables and performance after merger were examined. The findings indicate that both direct prediction and mediation are significant. Nevertheless, the level of mediation is relatively weak. Again, only three variables (out of six) are significant: 'trust', 'intention to leave' and 'knowledge transfer 1 '.

In the second path analysis, presented in Figure 5, the mediating effects of management's engagement on the relationships between employee-related and organisational variables and satisfaction with acquisition were examined. This model indicates that both the direct prediction and mediation are sig- 
nificant. Accordingly, the level of mediation is relatively weak. Like in the path analysis above, mediations for only three variables are significant: 'trust', 'intention to leave' and 'knowledge transfer 1 '.

Based on the two preceding path analyses, it can be stated that Hypotheses 3 and 4 were only partially supported, as the empirical data point to partial mediation. To summarise the main results of this study, it appears that both employees-related variables and organisational variables have some direct influence over acquisition success, and that management's communication and engagement has a partial mediating effect on these relationships. This is consistent with our theoretical reasoning and findings from the literature review, as the employee reactions and the organisational arrangements between the acquirer and the acquiring company determine success, yet they require effective communication and involvement of the local management to fully secure performance.

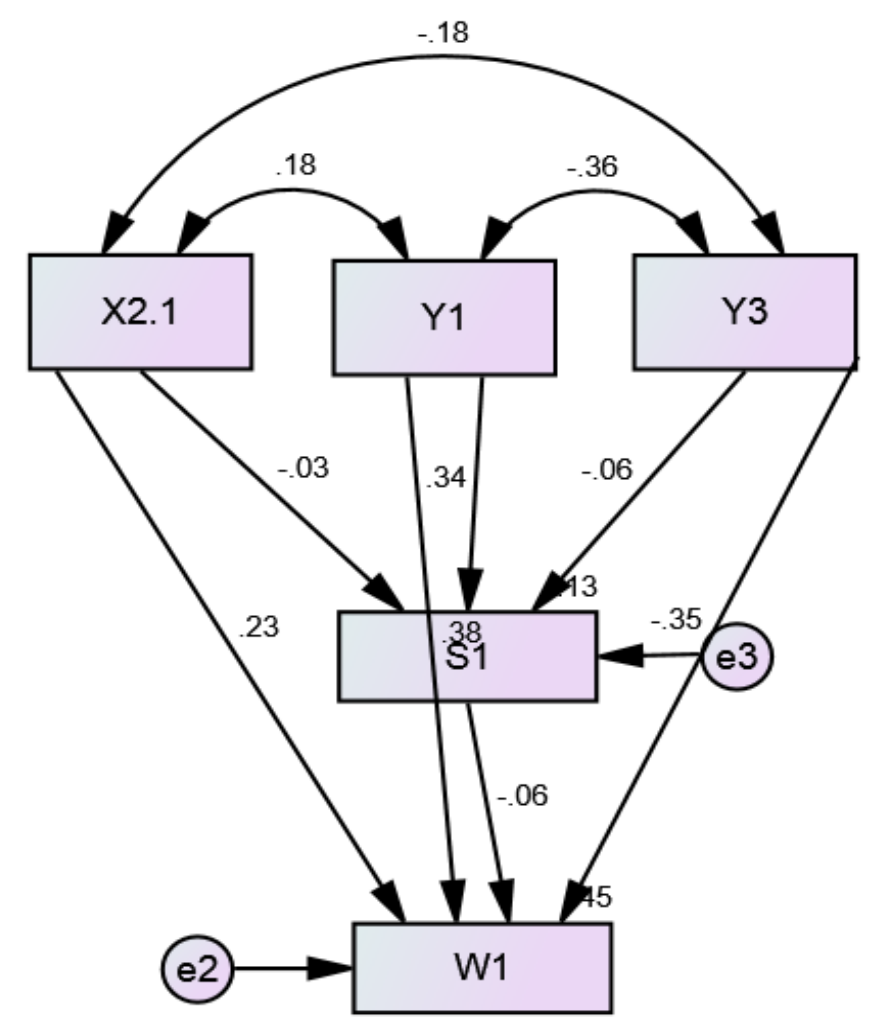

Figure 4. Path analysis model for 'perceived performance'

Annotation: dependent: W2 - satisfaction with acquisition; mediator:Z1 - management's communication), independent variables: (X2.1 - retained autonomy, Y1 - trust, Y3 - intention to leave). Source: own elaboration.

\section{DISCUSSION AND CONCLUSION}

\section{Contribution to extant research}

Various approaches common in studies on acquisitions have adopted individual or collective levels of investigation in order to explore behavioural aspects. Merely a limited amount of researchfocused on the firm level in order to explore behavioural issues related to the acquired firm. Furthermore, unlike the majority of the aforesaid studies, which concentrate on the acquiring firm's standpoint, this paper explores the target firm's view. In this paper we hypothesised the mediating effects of management engagement during the acquisition processes and the quality of communication delivered to the acquired company's employees by the management team. Our hypotheses were partly supported, as we found evidence of a partial mediation. 


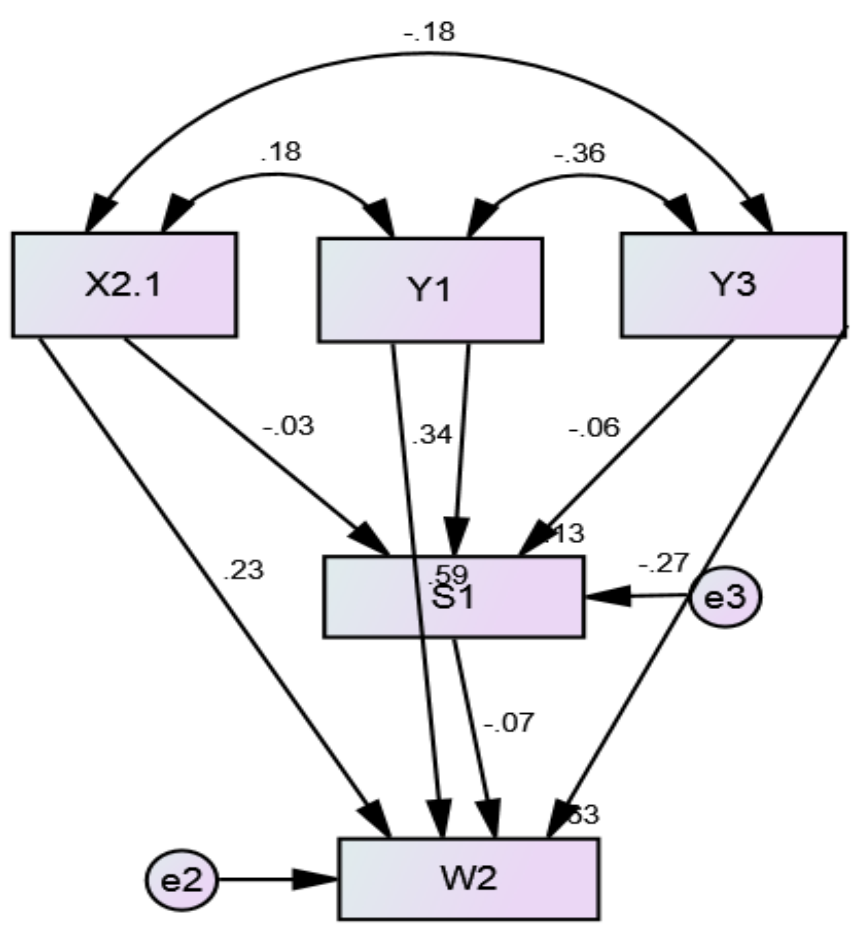

Figure 5. Path analysis model for 'satisfaction with acquisition'

Annotation: dependent: W2 - satisfaction with acquisition; mediator:S1 - management's engagement), independent variables: (X2.1 - retained autonomy, Y1 - trust, Y3 - intention to leave).

Source: own elaboration.

The mediating influence of management's communication resonates with earlier findings from literature, although this variable was mostly explored as a direct influence. Extant M\&A research has asserted that communication is crucial for a successful execution of the change process in an organisation (Schweiger \& Denisi, 1991). Mistakes in managing the communications may lead to rumours, which can aggravate negative emotions accompanying the change process and add to resistance to change among organisational members.

Hence, in the event of lacking or delayed communication from the management team, the members of an organisation may gain knowledge about the change process through other channels, such as media (Richardson \&Denton, 1996). Thus, start-ups, just like any other organisation, need to formally inform their employees on any critical change, including M\&A intentions. Indeed, as Vinten (1999) argues, the idea that in smaller organisations communication is appropriately addressed through informal channels is no more than a myth. Aleader's social competences are focal when attempting to pre-empt reactions on the part of the participants of the change process (Oreg, 2006).

On the other hand, while the related studies have agreed on the pivotal role of thoughtful communications, a number of researchers (e.g. Weber et al., 2012) demonstrate that over communication ought to be evaded, since organisational members have to retain a certain degree of ambiguity so as to remain flexible and able to deal with a dynamically changing situation. In practice, the members of an organisation may tend to refuse to discuss the challenging issue of the acquisition, due to limitations of the possessed information or due to the pre-occupation with negative side effects of the deal. However, such avoidance on the manager's part, or a manger's negative attitude, may in itself be perceived as information by employees (George \& Zhou, 2007).

With regard to the second of the stated mediation effects, our study corroborates earlier arguments about the relevance of the engagement of an appropriate leadership steering the change process. In fact, the main managerial competences which are crucial for a successful merger or acquisition pertain inter alia to carefully planning the timing of the integration process so as to complete it effectively. Not least, also the competence to motivate the members of both organisations 
to demonstrate cooperative behaviour, is of vital importance. In particular, the founder of the target firm is a key individual who had shaped the organization in a significant manner (Shane et al., 2003). It is the founder who is often closely associated with the sources of competitive advantage of the firm (Baum \& Locke, 2004), thus having more influence over employee motivation and over the company culture than professional managers.

\section{Limitations and future research}

It must be noted that this paper focused on the post-acquisition stage. Although extant research has indicated that the said stage is focal for the overall success of the deal, there are numerous other factors operating simultaneously at various stages of an acquisition. Thus, future studies measuring the influence of our research questions at various other parts of an acquisition deal may prove to be productive. The inclusion of the most influential contributors affecting each M\&A stage will probably allow the construction of a more holistic model.

The conclusions of this paper may also be to some extent confined by the culture of start-up organisations in Israel. in fact, a national culture determines the ways in which international investors are perceived (Moschieri \& Campa, 2014). Therefore, exploring the influence of national cultures on the acculturation process and outcomes of start-up acquisitions might yield different conclusions with regard to communication and management engagement during the integration after the acquisition deal. Furthermore, based on larger samples, a process perspective on changes in autonomy and its relationship with integration outcomes could be explored in a longitudinal design.

\section{REFERENCES}

Agarwal, R., \& Helfat, C. E. (2009). Strategic renewal of organizations. Organization Science, 20(2), 281-293.

Almor, T. (2013). Conceptualizing paths of growth for technology-based born-global firms originating in a smallpopulation advanced economy. International Studies of Management \& Organization, 43(2), 56-78.

Amiot, C. E., Terry, D. J., Jimmieson, N. L., \& Callan, V. J. (2006). A longitudinal investigation of coping processes during a merger: Implications for job satisfaction and organizational identification. Journal of Management, 32(4), 552-574.

Angwin, D. N., Paroutis, S., \& Connell, R. (2015). Why good things Don't happen: the micro-foundations of routines in the M\&A process. Journal of Business Research, 68(6), 1367-1381.

Rafferty, A. E., Jimmieson, N. L., \& Armenakis, A. A. (2013). Change readiness: A multilevel review. Journal of Management, 39(1), 110-135.

Armenakis, A. A., \& Harris, S. G. (2002). Crafting a change message to create transformational readiness. Journal of Organizational Change Management, 15, 169-83.

Avnimelech, G., \& Schwartz, D. (2009). Structural changes in mature Venture Capital industry: Evidence from Israel. Innovation Management, Policy \& Practice, 11(1), 60-73.

Baum, J. R., \& Locke, E. A. (2004). The relationship of entrepreneurial traits, skill, and motivation to subsequent venture growth. Journal of Applied Psychology, 89(4), 587-598.

Becker, J. U., Clement, M., \& Nöth, M. (2016). Start-ups, incumbents, and the effects of takeover competition. Journal of Business Research, 69(12), 5925-5933..

Bezrukova, K., Thatcher, S., Jehn, K. A., \& Spell, C. S. (2012). The effects of alignments: Examining group faultlines, organizational cultures, and performance. Journal of Applied Psychology, 97(1), 77-94.

Birkinshaw, J., Bresman, H., \& Håkanson, L. (2000). Managing the post-acquisition integration process: How the human integration and task integration processes interact to foster value creation. Journal of Management Studies, 37(3), 395-425.

Boeker, W., \& Wiltbank, R. (2005). New venture evolution and managerial capabilities. Organization Science, 16(2), 123-133.

Cefis, E., \& Marsili, O. (2006). Survivor: The role of innovation in firms' survival. Research Policy, 35(5), 626-641.

Cai, L., Chen, B., Chen, J., \& Bruton, G. D. (2017). Dysfunctional competition \& innovation strategy of new ventures as they mature. Journal of Business Research, 78, 111-118. 
Capron, L. (1999). The long-term performance of horizontal acquisitions. Strategic Management Journal, 20(11), 987-1018.

Chaudhuri, A., \& Holbrook, M. B. (2001). The chain of effects from brand trust and brand affect to brand performance: the role of brand loyalty. Journal of Marketing, 65(2), 81-93.

Cheng, C., \& Yang, M. (2017). Enhancing performance of cross-border mergers and acquisitions in developed markets: The role of business ties and technological innovation capability. Journal of Business Research, 81, 107-117.

Coff, R. W. (1999). How buyers cope with uncertainty when acquiring firms in knowledge-intensive industries: Caveat emptor. Organization Science, 10(2), 144-161.

Cooper-Hakim, A., \& Viswesvaran, C. (2005). The construct of work commitment: Testing an integrative framework. Psychological Bulletin, 131(2), 241-259.

Dashti, Y., Schwartz, D., \& Pines, A. (2008). High technology entrepreneurs, their social networks and success in global markets: The case of Israelis in the US market. In A. Rahim (Ed.), Current topics in management. 13 (pp. 131-144). Piscataway, NJ: Transaction.

Datta D.K. (1991). Organizational fit and acquisition performance: effects of post-acquisition integration. Strategic Management Journal, 12(4), 281-297.

De Fontenay, C., \& Carmel, E. (2004). Israel's silicon wadi: The forces behind cluster formation. In T. Bresnahan \& A. Gambardella (Eds.), Building high tech clusters: Silicon Valley and beyond (pp. 40-77). Cambridge, UK: Cambridge University Press.

Edwards, J. R., \& Lambert, L. S. (2007). Methods for integrating moderation and mediation: a general analytical framework using moderated path analysis. Psychological Methods, 12(1), 1.

Feather N.T. (1992). Expectancy-value theory and unemployment effects. Journal of Occupational \& Organizational Psychology, 65, 315-330.

Ferreira, M.P., Santos, J.C., Almeida, M.I.R., \& Reis, N.R. (2014). Mergers \& acquisitions research: A bibliometric study of top strategy and international business journals, 1980-2010. Journal of Business Research, 67(12), 2550-2558.

Galpin, T. J., \& Herndon, M. (2007). The complete guide to mergers and acquisitions (2nd ed.). San Francisco, CA: Jossey-Bass.

George, J., \& Zhou, J. (2007). Dual tuning in a supportive context: Joint contributions of positive mood, negative mood, and supervisory behaviors to employee creativity. Academy of Management Journal, 50(3), 605-622.

Gomes, E., Weber, Y., Brown, C., \& Tarba, S. (2011). Managing mergers, acquisitions and strategic alliances: Understanding the process. Hampshire, England: Palgrave McMillan.

Gomez, C., \& Rosen, B. (2001). The leader-member exchange as a link between managerial trust and employee empowerment. Group and Organization Management, 26(1), 53-69.

Graebner, M. E. (2004). Momentum and serendipity: How acquired leaders create value in the integration of technology firms. Strategic Management Journal, 25(8-9), 751-777.

Holt, D. T., Armenakis, A. A., Feild, H. S., \& Harris, S. G. (2007). Readiness for organizational change: The systematic development of a scale. Journal of Applied Behavioral Science, 43, 232-255.

Homburg, C., \& Bucerius, M. (2006). Is speed of integration really a success factor in acquisitions and acquisitions? An analysis of the role of internal and external relatedness. Strategic Management Journal, 27, 347367.

Hurley, R. F. (2006). The Decision to Trust. Harvard Business Review. September, 55-62.

Inkpen, A. \& Currall, S. C. (2004). The coevolution of trust, control, and learning in joint ventures. Organization Science, 15, 586-599.

Ivancevich, J. M., Schweiger, D. M., \& Power, F. R. (1987). Strategies for managing human resources during M\&A. Human Resource Planning, 10(1), 19-35.

Jimmieson, N., Terry, D., \& Callan, V. (2004). A longitudinal study of employee adaptation to organizational change: The role of change-related information and change- related self-efficacy. Journal of Occupational Health Psychology, 9, 11-27.

Jordão, R.V.D., Souza, A.A, \& Ewerton, A.A. (2014). Organizational culture and post-acquisition changes in management control systems: An analysis of a successful Brazilian case. Journal of Business Research, 67(4), 542-549.

Junni, P., Sarala, R. M., Tarba, S.Y., \& Weber, Y. (2015). The Role of Strategic Agility in Acquisitions. British Journal of Management, 25(4), 596-616. 
Junni, P., \& Sarala, R. M. (2013). The role of absorptive capacity in acquisition knowledge transfer. Thunderbird International Business Review, 55(4), 419-438.

King, D. R., Slotegraaf, R. J., \& Kesner, I. (2008). Performance implications of firm resource interactions in the acquisition of R\&D-intensive firms. Organization Science, 19(2), 327-340.

King, G. (2002). Crisis management \& team effectiveness: A closer examination. Journal of Business Ethics, 41(3), 235-249.

Krug, J. A., \& Hegarty, W. H. (2001). Predicting who stays and leaves after an acquisition: A study of top managers in multinational firms. Strategic Management Journal, 22, 185-196.

Krug, J. A., \& Nigh, D. (2001). Executive perceptions in foreign and domestic acquisitions: An analysis of foreign ownership and its effect on executive fate. Journal of World Business, 36, 85-105.

Krug, J.A. ,\& Aguilera, R.V. (2005). Top management team turnover in mergers and acquisitions. In C. Cooper \& S. Finkelstein (Eds), Advances in Mergers and Acquisitions, Vol. 1, JAI, New York, NY.

Larsson, R., \& Finkelstein, S. (1999). Integrating strategic, organizational, and human resource perspectives on mergers and acquisitions: A case survey of synergy realization. Organization Science, 10, 1-26.

Lim, M.-H., \& Lee, J.-H. (2016). The effects of industry relatedness and takeover motives on cross-border acquisition completion. Journal of Business Research, 69(11), 4787-4792.

Madsen, S. R., Miller, D., \& John, C. R. (2005). Readiness for organizational change: Do organizational commitment and social relationships in the workplace make a difference? Human Resource Development Quarterly, 16, 213-233.

Marks M.L. (1982). Merging human resources: a review of current research. Mergers \& Acquisitions, $17,38-44$.

Marks, M. L., \& Mirvis, P. H. (1986). The merger syndrome. Psychology Today, 20(10), 36-42.

Marks, M. L., \& Mirvis, P. H. (1997). Revisiting the merger syndrome: Dealing with stress. Mergers and Acquisitions, 31(6), 21-27.Mirvis

Meyer, J. P., \& Allen, N. J. (1997). Commitment in the workplace: Theory, research, and application. Thousand Oaks, CA: Sage.

Marks, M. L., \& Mirvis, P. H. (2001). Making mergers and acquisitions work: Strategic and psychological preparation. Academy of Management Perspectives, 15(2), 80-92.

Minbaeva, D. (2007). Knowledge transfer in multinational corporations. Management International Review, 47, 567-593.

Minbaeva, D., Pedersen, T., Bjorkman, I., Fey, C. \& Park, H.J. (2003). MNC knowledge transfer, subsidiary absorptive capacity and HRM. Journal of International Business Studies, 34(6), 586-599.

Mirvis, P. H., \& Marks, M. L. (1994). Managing the Merger: Making it Work. Prentice Hall, Paramus, New Jersey.

Moschieri, C., \& Campa, J.M (2014). New trends in mergers and acquisitions: Idiosyncrasies of the European market. Journal of Business Research, 67(7), 1478-1485.

Nadler, D. A., Thies, P. K., \& Nadler, M. B. (2001). Culture change in the strategic enterprise: Lessons from the field. CL Cooper, S. Carwright and PC Earley, The International Handbook of Organizational Culture and Climate. John Wiley \& Sons Ltd, Chichester.

Oberg, C., \& Tarba, S. Y. (2013). What do we know about post-merger integration following international acquisitions? Advances in International Management, 26, 471-494.

Oreg, S. (2006). Personality, context, and resistance to organizational change. European Journal of Work and Organizational Psychology, 15, 73-101.

Piderit, S. K. (2000). Rethinking resistance and recognizing ambivalence: A multidimensional view of attitudes toward an organizational change. The Academy of Management Review, 25, 783-794.

Popli, M., Ladkani, R.M., \& Gaur A.S. (2017). Business group affiliation and post-acquisition performance: An extended resource-based view. Journal of Business Research, 81, 21-30.

Puranam P., Singh H., \& Zollo M. (2002). The inter-temporal tradeoff in technology grafting acquisitions. Working paper, London Business School.

Rahman, M., Lambkin, M., \& Hussain, D. (2016). Value creation and appropriation following M\&A: A data envelopment analysis. Journal of Business Research,69(12), 5628-5635.

Ranft, A. L., \& Lord, M. D., (2002). Acquiring new technologies and capabilities: A grounded model of acquisition implementation. Organization Science, 13(4), 420-441. 
Ranft, A. (2006). Knowledge Preservation and Transfer During Post-Acquisition Integration. In C. Cooper \& S. Finkelstein, Advances in Mergers and Acquisitions, Vol. 5, (pp. 51-67), New York: JAI

Rhoads, K., Busenitz, L., \& Haines, H. (2012). Entrepreneurial Acquisition: Founder Retention Post- Acquisition, Asset or Liability?. Frontiers of Entrepreneurship Research, 32(4), 1-15.

Richardson, P., \& Denton, D. K. (1996). Communicating change. Human Resource Management, 35, $203-216$.

Santos, F., \& Eisenhardt, K. M. (2009). Constructing markets and shaping boundaries: Entrepreneurial power in nascent fields. Academy of Management Journal, 52(4), 643-671.

Schoar, A. (2002). Effects of corporate diversification on productivity. Journal of Finance, 57(6), 2379-2403.

Schoenberg, R. (2006). Measuring the performance of corporate acquisitions: an empirical comparison of alternative metrics. British Journal of Management, 17(4), 361-370.

Schweiger, D.M., \& DeNisi, A.S. (1991). Communication with employees following a merger: a longitudinal field experiment. Academy of Management Journal, 34(1), 110-135.

Seo, M., \& Hill, N. S. (2005). Understanding the human side of merger and acquisition: An integrative framework. Journal of Applied Behavioral Science, 41, 422-443.

Shane, S., Locke, E. A., \& Collins, C. J. (2003). Entrepreneurial motivation. Human Resource Management Review, 13(2), 257-279.

Simons, T. (2002). Behavioral integrity: The perceived alignment between managers' words and deeds as a research focus. Organization Science, 13, 18-35.

Stahl, G. K., Chua, C. H., \& Pablo, A. L. (2012). Does national context affect target firm employees' trust in acquisitions? Management International Review, 52(3), 395-423.

Terry, D. J., Callan, V. J., \& Sartori, G. (1996). Employee adjustment to an organizational merger: Stress, coping and intergroup differences. Stress Medicine, 12, 105-122.

Trąpczyński, P., Zaks, O., \& Polowczyk, J. (2018). The Effect of Trust on Acquisition Success: The Case of Israeli Start-Up M\&A. Sustainability, 10(7), 2499.

Vaara, E., Sarala, R., Stahl, G., \& Bjorkman, I. (2012). The impact of organizational and national cultural differences on social conflict and knowledge transfer in international acquisitions. Journal of Management Studies, 49(1), 1-27.

Van Dam, K. (2005). Employee attitudes toward job changes: An application and extension of Rusbult and Farrell's investment model. Journal of Occupational and Organizational Psychology, 78, 253-272.

Very, P., Lubatkin M., Calori, R., \& Veiga, J. (1997). Relative Standing and the Performance of Recently Acquired European Firms. Strategic Management Journal, 18(8), 593-614.

Vinten, G. (1999). Corporate communications in small- and medium-sized enterprises. Industrial and Commercial Training, 31(3), 112-119.

Vroom V. (1964). Work and Motivation. New York: Wiley. Wald.

Wanberg, C. R., \& Banas, J. T. (2000). Predictors and outcomes of openness to changes in a reorganizing workplace. Journal of Applied Psychology, 85, 132-142.

Weber, Y., Rachman-Moore, D., \& Tarba, S. Y. (2012). HR practices during post-merger conflict and merger performance. International Journal of Cross Cultural Management, 12(1), 73-99.

Weitzel, U., \& McCarthy, K. J. (2011). Theory and evidence on mergers and acquisitions by small and medium enterprises. International Journal of Entrepreneurship and Innovation Management, 14(2), 248-275.

Whitaker, S. C. (2012). Mergers \& Acquisitions Integration Handbook: Helping Companies Realize the Full Value of Acquisitions. Hoboken: Wiley.

Zaks, O., Polowczyk, J., \& Trąpczyński, P. (2018). Success factors of start-up acquisitions: Evidence from Israel. Entrepreneurial Business and Economics Review, 6(2), 201-216.

Zhou, J., Shin, S. J., \& Cannella Jr, A. A. (2008). Employee self-perceived creativity after mergers and acquisitions: Interactive effects of threat-opportunity perception, access to resources, and support for creativity. The Journal of Applied Behavioral Science, 44(4), 397-421.

Zollo, M., \& Meier, D. (2008). What is M\&A performance? Academy of Management Perspectives, 22(3), 55-77. 


\section{Authors}

The contribution share of authors is equal and amounted to $33 \%$ each of them.

\section{Jan Polowczyk}

Habilitated doctor, Associate Professor at the Poznań University of Economics and Business, Department of International Competitiveness. He spent 15 years in the corporate sector, holding senior managerial positions in Polish affiliates of international companies. The main field of his interests is strategic management. He is a member of Strategic Management Society.

Correspondence to: Prof. UEP, dr hab. Jan Polowczyk, Department of International Competitiveness, Poznań University of Economics and Business, Al. Niepodległości 10, 61-875 Poznań, Poland, e-mail: jan.polowczyk@ue.poznan.pl

ORCID (1) http://orcid.org/0000-0002-0613-6924

\section{Ofer Zaks}

$\mathrm{PhD}$, lecturer and researcher at the Department of "Management of Service Organizations" in the Jerusalem Hadassah college, Israel. He was previously employed as a management team member (VP HR) in various firms - low \& high-tech. In his research he concentrates on factors that influence the success of M\&A processesmainly in high- tech \& start-ups companies \& on Industry 4.0.

Correspondence to: Dr Ofer Zaks, Jerusalem Hadassah College, HaNevi'im 37, HaHavatselet 8, Jerusalem, Israel, e-mail: zaks-@013.net.il

ORCID (1) http://orcid.org/0000-0001-8154-9174

\section{Piotr Trąpczyński}

Habilitated doctor, Associate Professor at the Poznań University of Economics and Business, Department of International Competitiveness. He acts as one of directors at the Knowledge Transfer Company of the same university, supporting firms in their international expansion. In his research work, he concentrates on the performance outcomes of firm internationalisation. His work has been published inter alia in the Journal of Business Research, Journal of World Business, International Business Review, or the European Management Journal. He is board member and co-founder of the AIB-CEE Chapter.

Correspondence to: Prof. UEP, dr hab. Piotr Trąpczyński, Department of International Competitiveness, Poznań University of Economics and Business, Al. Niepodległości 10, 61-875 Poznań, Poland, e-mail: piotr.trapczynski@ue.poznan.pl

ORCID (1) http://orcid.org/0000-0001-8154-9174

\section{Conflict of Interest}

The authors declare that the research was conducted in the absence of any commercial or financial relationships that could be construed as a potential conflict of interest.

\section{Copyright and License}

This article is published under the terms of the Creative Commons Attribution - NoDerivs (CC BY-ND 4.0) License http://creativecommons.org/licenses/by-nd/4.0/ 